\title{
良導絡と睡眠に関する考察
}

愛知学院大学齿学部生理学教室

佐藤 豊 彦

さて、本稿で筆者が敢えて良導絡と睡眠との 間に何物かの関連を見出そうと試みたのには一 応それなりの理由があっての上であるととは論 を俟たない。睡眠は行動の停止と意識の消失、 そして睡眠終了と同時に完全に正常な覚醒状態 への復州、として定義されうるであろうが、そ れ丈では不十分で、脳活動状態と行動との間に 一定の対応関係が常に見出される必要がある。 大部分の彴虫類及び両棲類以下の動物では、行 動停止中之行動中の脳活動状態の間に明確な差 異がない。てれに対して、より高等な鳥類では その差異が明らかであり、更に高等な哺乳類に なって初めて明確な睡眠の発達が認められる。 即ち、睡眠はより高度に発達した脳の活動に随 伴して生じるものと考えられる。そして、睡眠 中には運動系の変化によって行動停止が生じ、 感覚系の変化によって感覚閾值が上昇するのみ ならず、自律神経系にも著しい変化が見られ る。例えば、眠りから目覚めた時に寝汗をかい ているのを発見するととがあるととからあ分る 如く、睡眠中の汗腺活動の変化は意外に大き く、しかす睡眠の推移と一定の関係が明瞭に認 められる。此処で、良導点の成立に恐らく最も 重要な関係があるのは活動汗腺の存在 ${ }^{1}$ である ことを考え併せれば、覚醒時の良導点は睡眠中 のそれとは必らずしも同一ではない可能性が出 て来るであろう。そうなれば、覚醒時の良導絡 とは異った、睡眠時の良導絡を導き出すととが 出来るかす知れない。更に想像を遈しくすれ ば、或る疾患に対して有勃な治療点を覚醒時の 良導点からは得られなかった場合にあ、睡眠中 には勃果的な良導点を得るととが出来るかす知 れない。

以上の様な論拠から、以下、睡眠の生理学に ついて概説すると共に、特に自律神経系活動の 
睡眠中における特徴についてやや詳細に 記述 し、将来の良導絡研究の一助にならんととを希 j。

\section{II 睡眠一一その意義と中枢機序}

1. 生理的意義

睡眠の指標として最す良く利用されるのは脳 波である。行動上の入眠と共に、脳波の振幅は 次第に高くなり、周波数が低下する。睡眠深度 が進むに連れて、高振幅徐波化の傾向は次第に 強くなる。このため、普通の睡眠は徐波睡眠 (slow wave sleep) と呼ばれる（因 2)。徐波 睡眠は、脳波パターン、覚醒閾値などから、大 抵はIV期に分けられる。徐波睡眠が90分位続く と、一旦急速に覚醒若しくはそれに非常に近い レベルまで戻る。昼漫の場合だと、大抵は此処 で起きて了うが、夜間では引き続いて次のサイ クルへ入る。明け方に向うに連れて、睡眠深度 は浅いものが多くなって来る。然し、サイクル 間の境い目のところで異質な睡眠相が発現する ようになる（図2）。この時の脳波は入眠相で ある徐波睡眠深度第 I 度のうとうと状態のもの と全く区別がつかないが、実は極めて深い睡眠 で、覚醒閾值は徐波睡眠而度又はそれよりあゃ や高い位である。この時、四肢の筋肉の緊張は 殆ど完全に消失する（徐波睡眠は、如何にそれ が梁くとあ、筋緊張が完全に消失するととはな い）。とてろが、この緊張消失の背景の上に、 四肢筋の短かくて急速な鲝卛が散発的に発現す る。同時に、眼球が様々な方向へ痙攣性の運動 を示す。また、この睡眠相では夢を見ていると とが多い（徐波睡眠相では夢を見るととは殆ど ない）。この様に、此の睡眠相では、脳波を見 ている限り、非常に浅い眠りの筈であるのに、 実は非常に深い眠りであり、それでいながら、 夢を見ると言う精神活動が可能である。更に、 筋の完全弛緩がありながら、痤攣様の筋運動が 頻発する、と言った具合に、一般的常識からは 矛盾する面が非常に多い。従って、この睡眠相 は逆説睡眠（paradoxical sleep）と呼ばれる。 急速眼球運動の 群発が非常に特徵的でもある ので、 rapid eye movement sleep (略して、 REM sleep）とも呼ばれる。
図 2 終夜睡眠の経過3)

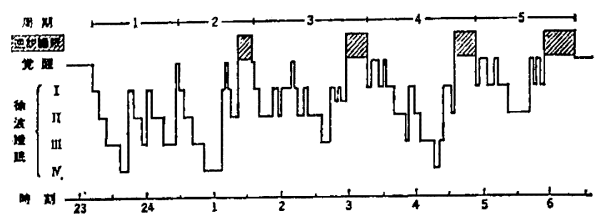

さて、上記 2 種類の睡眠相の関係であるが、 正常時には、必らず徐波睡眠が先行する。逆説 睡眠が起とるための準備操作は徐波睡眠中に行 なわれると考えられる。全く睡眠をさせなかっ た場合、その直後に起こった睡眠であ同様であ る。約11日間の断眠を行なった報告があるが、 その間、幻覚、情動制御の不良などの精神症状 が発現するが、一晚の睡眠によって、精神症状 は完全に消失する。そして、この一晚の睡眠中 の徐波及び逆説睡眠の発現パターンは、普段の パターンと全く同じで、入眠直後の深い徐波睡 眠がほんの少し増加する程度である。一睌の全 睡眠量は殆ど変らないわけである。即ち、睡眠 負倩は殆ど返斉されていないままで正常機能が 回復する。例えば、運動時の酸素負債は必らず 何らかの形で完全に返斉されるので、これは極 めて物理化学的立場で制御されていると言えよ う。これに対して、睡眠制御系は大きな柔軟性 (plasticity) を持っているととになる。

全身の細胞の新陳代謝に不可欠である成長小 ルモンの分泌は、専ら徐波睡眠期に起こる。日 常体験する睡眠直後の双快感、逆説睡眠に対す る優先性、脸の発達発育程度之睡眠との関係、 などを考え併せると、徐波睡眠は、個体と言う 有機的に結合した器官系の機能の健全性を保つ ために、中枢神経系が周期的に執らねばならな い機能状態と言いうるかあ知れない。てれに対 して、逆説睡眠であるが、逆説睡眠が始まった ら直ちに覚醒させる、と言う方法で逆説睡眠を 完全に奪ってみてあ、多少の情動変化（いら立 ちなど）のみで、著明な異常は来たさないと言 われる。然し、逆説睡眠中に運動・感覚・自律 神経系に見られる変化は激烈とあ言って良い程 で、徐波睡眠中の変化とは比べすのにならな い。覚醒下の運動時、精神的緊張時と比肩しう 
る、或は時にはそれ以上の大きな変動が逆説睡 眠中には起とりうる。従って、逆説睡眠中に は、どちらかと言えば、各器官系或は各器官毎 に、独立した運動律の下に活動が行なわれてい るかの如き印象を受ける。いわば、機械の部品 の一個一個を改める作業を行なっているかの如 くである。骨格筋を例に挙げると、最も深い徐 波睡眠中でさえ、一つの筋肉内の多数の筋肉細 胞は収縮運動を行なっている。逆説睡眠中には 収縮は全くなくなる（散発する座攣性収縮を除 く）。筋肉を栄養している血管は、筋収縮中に は当然圧迫され、血流が杜絶することすある。 従って、筋の完全弛楥は最大の筋血流量を与え ることになり、筋の代謝状態にとっては極めて 好都合となる。効果は未だ其の他にす色々と考 えられる。筋の収縮がある時には、筋の内部及 び周辺部にある様々な感覚受容器が興应し、中 枢神経へ情報を送り続けており、中枢はそれら の情報を利用して色々な判断を下している等で ある。とてろか、逆説睡眠中にはそうした情報 が無くなるので、中枢神経系は一部の入力情報 が欠落したままで判断を下すと言う、いわば実 験的条件下で自己の機能を試す機会が与えられ ることになる。筋肉以外のあのについては、想 像を迫しく出来るだけの情報が未だ十分ではな いので、明確には言えないが、大まかな印象と しては、徐波睡眠は個体全体の機能の安定平衡 を主眼としているのに対し、逆説睡眠はすっと 細分化された、器官や組織の機能を問題にして いるようである。

\section{2. 中枢神経機序}

a . 徐波睡眠の発現機序

中枢神経機序解明の最す単純な古典的手法 は、末梢組織に於けると同様に、破壊と刺激で ある。先ず脊䯣を含めた末梢組織が重要性を有 するか否かを知るために、延䯣と脊髄の間で脳 を切断して長期間生存せしめる試みが、ネコを 用いて行なわれた結果、その動物は正常のもの と同様な覚醒睡眠周期を繰り返すととが分っ た。即ち、睡眠の主たる発現機序は延骾以上の 脳内に局在する。中脳と間脳の間で切断した標 本では、大脳皮質脳波をみる限り、持続的な睡 眠状態にあることが確認された。即ち、大脳を
覚醒状態に維持するためには、中脳〜延䯣の何 処かの組織が必要である。中脳の中心部に存在 する網様体を破壊すると、大脳皮質脳波は持続 的に睡眠のパターンを示すと共に、行動上す昏 睡状態你り、強い感覚刺激を与えてむ、決し て覚醒させることは出来ない（以上、因 3 参 照)。中脳網様体を䉓気刺激すると、眠ってい た動物は覚醒する。以上より、中脳網様体が賦 活系 (activating system) として働らくととに よって覚醒が起てることは明らかとなったか、 睡眠の成立が賦活系の活動低下のみに依存して いるかどうかは不明である。そこで、積極的に 睡眠を起こさせるような抑制系の存在が追求さ れた。その結果、下位脳幹に存在する、セロト ニンを含んだ释線核（てれについては、本誌で 別の機会に述へる予定である）、延䯣の孤束核

（血圧、内臟感覚の面で極めて重要な核）、視 床下部の最前部、などが徐波睡眠の成立に積極 的に関与しているととが明らかとなった。てれ らの詳細に関しては、拙著の総説2)を御覧戴け れば幸いである。

図 3 䟼活系と抑制系の局在 ${ }^{3)}$

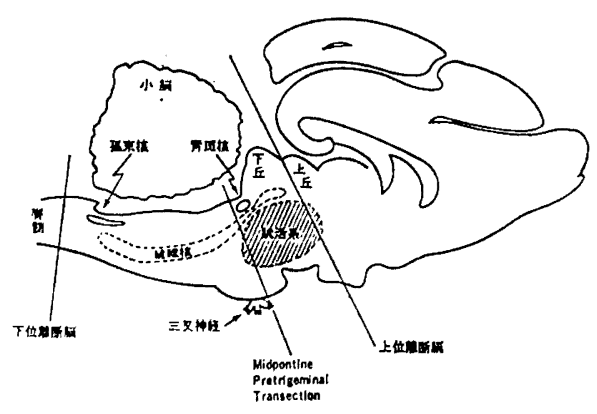

b. 逆説睡眠の発現機序

逆説睡眠に最も重要な役割を果しているの は、橋吻側部の背側に存在する青斑核であると 考えられる。との核はノルアドレナリンを含有 する神経細胞が密集している点で極めて特異な 存在である。青斑核を両側性に破壊すると、逆 説睡眠の発現が抑制される。然し、次第に代䐝 機能が働らいて、逆説睡眠が回復して来るの で、未知の組織が何らかの重要性を有するとと は疑いない。 


\section{III 睡眠中の生理的指標の変動}

\section{1. 体性神経系}

睡眠深度の各段階に応じて脳波パターンは可 成り鋭敏に变化する（図 4)。個人差は多少あ るが、基本的には驚く程よく似ている。開拓期 の脳波研究者が期待した、知能や個性との関連 は全くないと言って良い。然し、とれを裹返し て考えれば、個人差に考慮を払わずに安心して 使用出来ると言う点で、脳波は睡眠研究にとっ て極めて有用な武器である。

図 4 睡眠段階と脳波パターン3

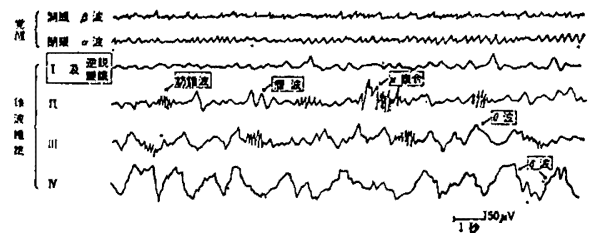

先ず感覚系について。眠っているヒトに感覚 刺激を与えてあ、閾値が上昇していて、仲々覚 醒に到らせ得ないととから、与えた感覚刺激が 大脳皮質感覚領野に到達する以前に、何処かで ブロックされているのではないか、と考えられ ていたが、電気生理学的手法を用いて、誘発電 位を測定してみると、徐波睡眠中には、大脳誘 発電位の振幅は覚醒時よりもむしろやや大きい ことが分った。従って、良導点に対する物理的 加療操作は睡眠中でも中枢神経系に対して十分 の影響を与えうるのみならず、返ってより効果 的であるかす知れないし、更に、覚醒時とは異 った質の影響を与えうるような受け入れ態勢が 出来ている可能性があろう。即ち、冒頭で述へ た如く、覚醒時とは異った良導絡を考えうる素 地があるわけである。勿論、良導点そのあのが 変化することあ計算に入れねばならない。

逆説睡眠中には誘発電位の振幅は極めて小さ くなるのが一般的である。感覚系は本来、随時 状況に応じて、各個の入力情報源を別々に切り 捨てうるように作られている。例えば、熱心に 耳を凝らしている時には視覚・触覚などの他の 感覚が䠅かになるようなものである。逆説睡眠 中には、こうしたブロック機構が到る所で強く
作動するととが証明されている。従って、逆説 睡眠に特有な良導絡の存在の可能性も極めて強 いと言って良かろう。

運動系について。徐波睡眠中には四肢の動き は全くない。睡眠サイクルの切れ目で寝返りを 打ったり、溜め息をついたりする程度である。 然し、四肢の筋肉を支配している大脳皮質運動 野の神経細胞の活動頻度の平均值は必らずしも 減少してはいない。むしろ増加する場合ああ る（図 5)。特に、時として認められるニュー ロンの群発性放電は容易に A $\boldsymbol{\alpha}$ 運動ニューロン を発火させ、筋の収縮が生じてもよさそうに思 える。ところが関節運動は起こらないので、何 らかの抑制機序が働らいて、最終的には運動が 起てらないようになっている。逆説睡眠中には このような傾向が極めて顕著になる。皮質運動 野のニューロンは覚醒時よりも遙汃に高い頻度 で興舊するにも拘わらず、筋の緊張は全く失わ れる。その理由は図6亿示した如く、A $\alpha$ 運動 ニューロンの静止膜電位が著しく過分極方向に 移動させられた為に、興翼性の入力が多数やっ

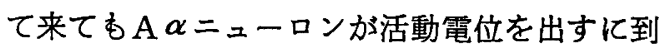
らないからである。こうした過分極を生じるた めには、A $\alpha$ ニューロンを支配する多数の抑制 性介在ニューロンが活動する必要がある。とと

図 5 皮質運動野ニューロンの活動パターン3)

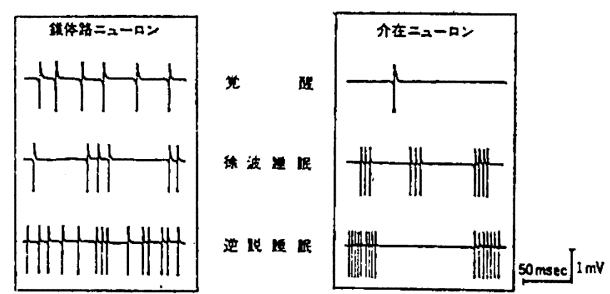

図 6 ネコ脊髄 $\mathrm{A} \alpha$ 運動ニューロンの膜電位 ${ }^{3}$

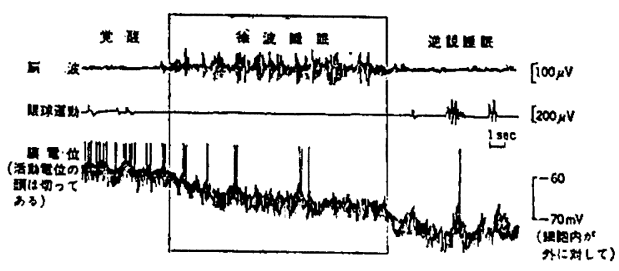


ろが、逆説睡眠中の急速眼球運動の群発に同期 して、脊髄の $\mathrm{A} \boldsymbol{\alpha}$ 運動ニューロンへも強力な促 進性入力が到来するのて、、背景にある強力な抑

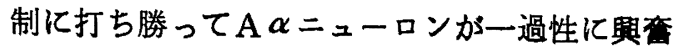
し、四肢筋の座摰性単収縮が起こる。これを自 動車に例えれば、アクセルとブレーキの両方を 一杯に踏んでいるのが逆説睡眠に相当するとと になる。時としてアクセルの踏み方が更に強く なった場合に、車はガクンと一歩前進するわけ である。兔す角、運動系は逆説睡眠中には高速 回転をしており、抑制系の働らきが辛うじて睡 眠中の不動化状態を保っている。抑制的制御の 失敗が急速眼球運動や四肢の痙彎として表現さ れる。恐らく夢を体験するのあ同様な機序が根 底にあるためであろう。

2、自律神経系

a. 発汗

全身の汗腺はほほ同期して興奪する。各汗腺 の興逳の強さは多少異るが、その細かな差異に ついては未だ明らかではない。立位の場合の発 汗速度の変動は極めて大きい（困 7）。背臥位 になると、直ちに発汗速度は著明に抑えられ、 安定化する。乙れは恐らく、皮府王迫刺激が汗 腺活動住して強力な制御作用を有しているか らであろう5)。徐波睡眠に入ると発汗速度は増 加し始める。睡眠深度の進行とよく平行して発 汗速度は增加する（図 8）。睡眠の第 1 サイク ルが終了し、睡眠深度が急激に浅くなると、発 汗速度も急速に低下する。明け方に向うに連れ て睡眠は一般に浅くなる傾向があるが、発汗速 度すとれと全く同様な傾向を示す。逆説睡眠中 には原則として発汗速度は極めて低い水準にあ るが、時として一過性の発汗突発が見られるて とがある。とうした現象は多くの場合、急速眼 球運動の群発と一致して起てるので、夢の体験 に伴う精神性発汗である可能性がある。

以上の如く、覚醒時には、発汗の変動のため に皮庙電気抵抗は刻々と大幅に変化して定め難 い。これに対して、徐波睡眠中は発汗速度が安 定するので、良導点の決定には大変好都合な時 期と言える。更に、脳波上の睡眠深度を考慮に 入れれば、新らたな、有意義な良導絡概念を導 出し得るかも知れない。大変興味深い課題と思
われる。

図 7 睡眠段階（上段）と発汗速度（下段）との 関係。背卧位 (supine) になると、発汗速度 は急速似低下する4)

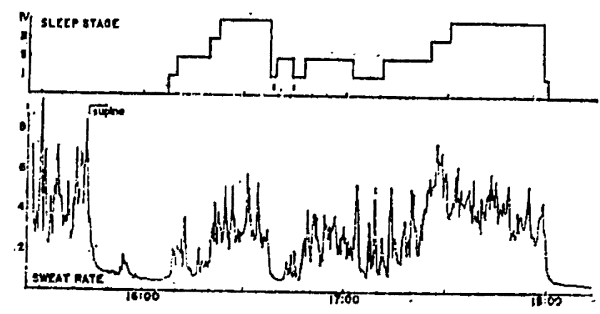

図 8 終夜睡眠経過と発汗速度の関係を 4 例の被 験者について示した。睡眠深度 I の部分で斜 線を施してあるとてろは逆説睡眠であり、そ の中で処々黒く塑ってあるとてろは、急速眼 球運動の存在を示すの)
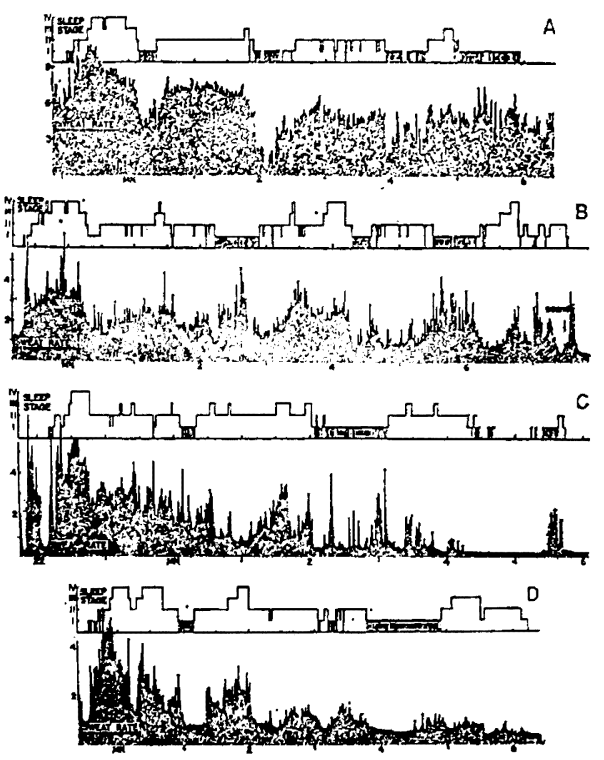

b. 循環系

指尖に反射光電式容積脈波ピックアップを当 てて観察すると、徐波睡眠中には脈波の振幅が 大きくなり、振幅の変動も非常に少なくなる （因 9）。時として一過性の血管収縮を示す、 いわゆる鋸歯状波が見られる以外は、非常に安 定している。乙れに対して、覚醒時や逆説睡眠 時には、脈波の振幅は小さく、振幅変動が大き く、非常に不安定なパターンを呈する。 血圧は徐波睡眠中にはやや低下し、安定化す る。逆説睡眠中には変動が著明で、覚醒時と似 
たパターンを示す。

末梢微小循環動態は皮府温、皮简湿潤度など に重要な影響を有するので、良導点の決定にも 関与している筈である。徐波睡眠中の循環動態 は逆説睡眠や覚醒時とは明らかに異なるので、 てれが良導点に対して何う影響しているかは極 めて興味ある問題である。

図 9 睡眠中のポリグラム。左; 逆説睡眠直前の 徐波睡眠中の記録。中央; 逆説睡眠中で、一 過性の発汗突出が見られた例。右; 逆説睡眠 の終了間際で、徐波睡昵に移行しようとする 時期。各記録は、上から、眼球運㲎、手掌䉓 位変動、前腕電位変動、手掌電気抵抗、前腕 軋気抵抗、手掌発汗速度、胸部発汗速度、指 尖容皘脈波、呼吸運動、時刻6)

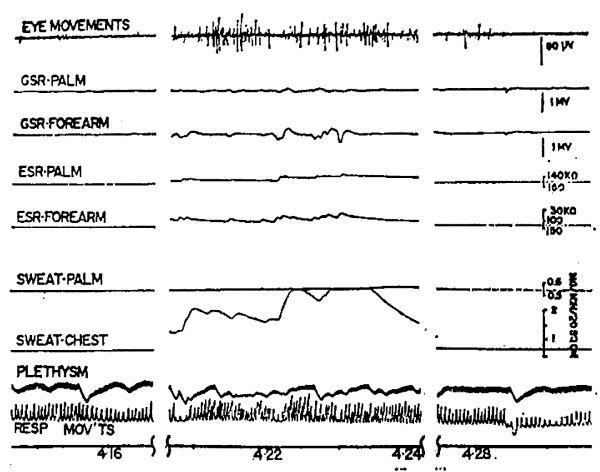

c. 体温

直腸温は明け方に向って徐々に低下する。発 汗によって体温が奪われるととも一因となって いるが、より大きな要因は、体温調節中枢がサ 一カディアンリズム（概日リズム、24時間リズ ム）の指令下で色々な因子を制御するととであ る。徐波睡眠深度が変化してす、直腸温は鋭敏 には反応しないが、逆説睡眠中には、若し環境 温が体温よりも高ければ、直腸温は上昇し、著 しい低温環境では下降する。即ち、逆説睡眠中 には、体温調節中枢の制御機能不良が起とり、 あたかす変温動物であるかの如き状態に置かれ ていることになる。

脳は温度が最も安定している器官の一つであ るが、睡眠相と樑い関係のある変動を示すのが 大きな特徵である。ネコで測定した結果では、 徐波睡眠に入ると共に脳温は徐々に低下し、逆 説睡眠に入ると著明な上昇を示し、時には覚醒
時の水準よりも高くなる（図10）。逆説睡眠時 には神経細胞の発射頻度が上昇するので、その 分だけ物質代謝が盛んになる結果、温度が上昇 するととも一因であるが、ネコなどの一部の動 物では、脳に血液を送り込む頸動脈か、、脳に入 る直前に細汃枝分れして網目状となり、放熱 し易い構造を有していることが極めて重要な関 係を有する。即ち、普段は血液は脳を泠却する 作用を有するわけだが、逆説睡眠中には上記の 網目状血管が収縮するために、血液の温度が高 いままで脳に達するので、脳温が上昇する。ヒ トではそのような構造はないので、恐らく変化 はむっと少なかろうと想像される。

体温は非常に多くの種類の要因によって決定 されるので、その変動の原因の解析は仲々困難 であるが、逆に、体温が変化すると、多種の生 理機能、特に自律神経系に対して強い影響を持 つので、良導点の決定に際しては、少なくとも 皮庙温の分布に関する資料を蓄皘するととは、 将来の研究の重要な礎となるであろう。

図10 ネコの脳温と覚醒睡眠周期との関係7) $A$; 覚醒。S S ; 徐波睡峮。DS; 逆説 睡眠。記録は上加ら、脳波、頸筋筋笔困、 外側視床下部温、視束前野温、大脳皮質 温、時間軸（1 分刻み）。

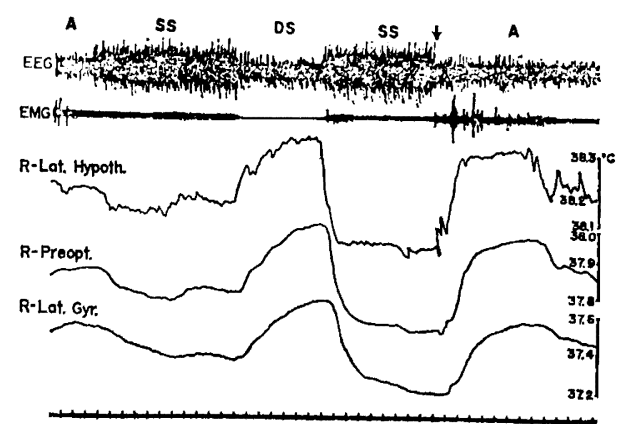

\section{IV 結 語}

睡眠時と覚醒時とでは、身体末梢組織と中枢 神経との間のダイナミックな結合様式に明らか な差が存在する。その差は単なる量的なすので はなく、多くの面で質的にも異る。従って、従 来の良導絡の概念を更に豊かなあのにするため に、睡眠中の生理機能に目を向けるととは重要 と思われる。睡眠発現の中枢神経機序として は、過去約20年間にわたって、モノアミン含有 
神経細胞群が大いに問題にされて来たが、最近 はペプチドを含有する神経細胞群が登場しつつ ある。良導絡を考える上で、とれらのニューロ ン群の働らきは、将来必らず重要な地位を占め るであろう。本稿では睡眠を採り上げて論じた わけだが、未だ他にす色々と重要な、我々が日 常生活でしばしば置かれる、生理的状態があ る。例えば、運動負荷時、季節に伴う温度順化 なよ゙、良導絡を考える上で有用な背景として大 いに考究されるべきであろう。

\section{参考文献}

1. 佐藤豊彦。発汗之皮唐の電気抵抗との関係 について。日良自律誌、29:42-43、1984。

2. 佐藤豊彦、江口国博。網様体の生理学 催眠系 (hypnogenic system) —。神経進
歩、 25 : 1036-1049、1981。

3. 佐藤豊彦。睡眠。「生理学（図説）」、東 西医学社、p.249-259、1983。

4. Satoh, T., Ogawa, T. and Takagi, K., Sweating during daytime sleep., Jap. J. Physiol., 15 : 523-531、1965。

5. 高木健太郎。生体の調節機能。中公新書、 1972 。

6. Ogawa, T., Satoh, T. and Takagi, K., Sweating during night sleep., Jap. J. Physiol., 17 : 135-148、1967。

7. Satoh, T., Brain temperature of the cat during sleep., Arch. ital Biol., 106 : 7382, 1968 。 